\title{
ENVIRONMENTAL GEOCHEMISTRY OF PTOLEMAIS LIGNITES, INTERMEDIATE STERILES, AND COMBUSTION PRODUCTS
}

\author{
Megalovasilis P. ${ }^{1}$, Godelitsas A. ${ }^{2}$, Papastergios G. ${ }^{3}$ and Filippidis A. ${ }^{3}$ \\ ${ }^{1}$ Technological Educational Institute of Ionian Islands, Department of Environment Technologists, \\ Division of Natural Environment Technologies, 29100, Zakynthos, Greece,pmegal@teiion.gr \\ ${ }^{2}$ University of Athens, Faculty of Geology \& Geoenvironment, 15784, Athens Greece, \\ agodel@geol.uoa.gr \\ ${ }^{3}$ Department of Mineralogy-Petrology-Economic Geology, Aristotle University of Thessaloniki, \\ 131 Egnatia St.Thessaloniki 54124, Greece,gpapaste@geo.auth.gr; anestis@geo.auth.gr
}

\begin{abstract}
The environmental geochemistry of lignite, intermediate sterile, fly ash and bottom ash samples from Ptolemais area, has been investigated. The chemical analyses of major elements, combined with SEM-EDS, showed that Si, Ca and Fe, are the most abundant elements and associated with various micro-particles. On average, the most abundant trace elements in the lignite samples are Ba (128 ppm), $\mathrm{V}(123 \mathrm{ppm}), \mathrm{Cr}$ (108 ppm), Sr (107), Ni (43 ppm), in intermediate sterile samples Ba (209 ppm), Sr (209 ppm), Cr (104 ppm), Ni (76 ppm), Zr (67 ppm), Zn (57 ppm), V (53 ppm), in fly ash samples Ba (455 ppm), Sr (336 ppm), Ni (180 ppm), Cr (160 ppm),V (110 ppm), $\mathrm{Zr}$ (102 ppm), Zn (74 ppm), Cu (71 ppm), Rb (62 ppm) and in bottom ash samples $\mathrm{Ba}$ (250 ppm), Cr (214 ppm), V (174 ppm), Sr (153 ppm), Ni (105 ppm), Zr (56 ppm), Zn (40 ppm).
\end{abstract}

Keywords: Greece, trace element, bottom ash, fly ash, environment.

\section{Пєрíi}

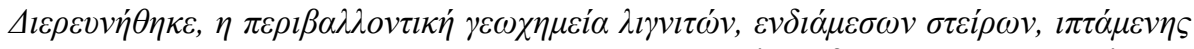

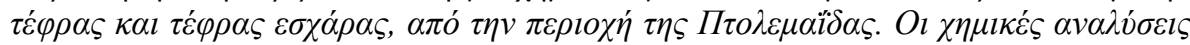

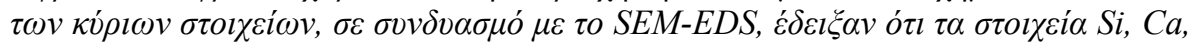

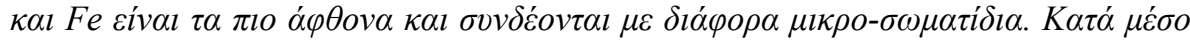

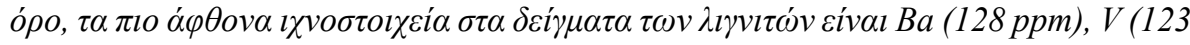

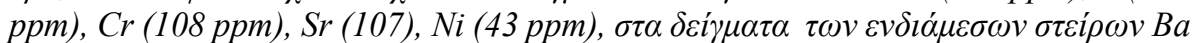
(209 ppm), Sr (209 ppm), Cr (104 ppm), Ni (76 ppm), Zr (67 ppm), Zn (57 ppm), V

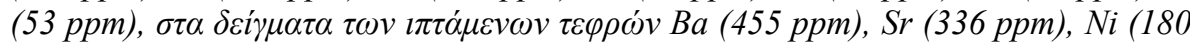
ppm), Cr (160 ppm), V (110 ppm), Zr (102 ppm), Zn (74 ppm), Cu (71 ppm), Rb (62

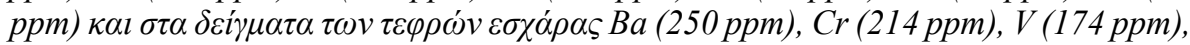
Sr (153 ppm), Ni (105 ppm), Zr (56 ppm), Zn (40 ppm).

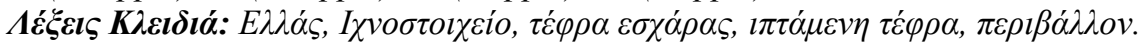




\section{Introduction}

Greece is second among EU countries for lignite coal production, with coal reserves of 3900 million tonnes at the end of 2007. The principal lignite production areas comprise the Ptolemais and Amyntaion lignite fields in Macedonia (N. Greece), which contribute 80\%, and the Megalopolis area in the Peloponnese contributing 20\%. In the greater area of Ptolemais six power stations operate with a total capacity 4388MWe (Petrotou et al., 2010, 2012; Megalovasilis et al., 2013). The geochemical character of coal deposits depends mainly on factors related with the coal (nature of the original plant material), the environment of deposition (geological setting and the physicochemical conditions applied after buried the age and rank of the coal, the activity of groundwater, and the weathering conditions of coal (Filippidis and Georgakopoulos, 1992; Georgakopoulos et al., 1994; Filippidis et al., 1996). All these factors control which elements are enriched, depleted or just present in the coal (Valcovic, 1983; Foscolos et al., 1989; Swaine, 1990; Finkelman, 1999).

During lignite combustion the major, minor and trace elements may concentrate in fly ash, while the mineral matter undergoes a series of physical and chemical changes (Filippidis and Georgakopoulos 1992; Yan et al., 2001; Vamvuka et al., 2004; Koukouzas et al., 2007, 2009; Vamvuka et al., 2009; Vejahati et al., 2010). Lignite combustion processes result in emission of particulate matter to the environment resulting in high enrichment of certain elements against local soils or road dusts, such as $\mathrm{S}, \mathrm{Cl}, \mathrm{Cu}, \mathrm{As}, \mathrm{Se}, \mathrm{Br}, \mathrm{Cd}$ and $\mathrm{Pb}$, and moderate enrichments in other elements e.g. $\mathrm{Ti}, \mathrm{Mn}, \mathrm{Mg}$, Al, Si, P, Cr (Kolovos et al., 2002a, b; Zeevaert et al., 2006; Petaloti et al., 2006; Iordanidis et al., 2008; Petrotou et al., 2010, 2012). One of the major problems that concerns the local authorities in the greater area of Ptolemais, and can easily be seen, is the respirable dust spread by winds from stock piles. In addition, lignite contains natural radionuclides ${ }^{238} \mathrm{U},{ }^{226} \mathrm{Ra},{ }^{210} \mathrm{~Pb},{ }^{232} \mathrm{Th}$ and ${ }^{40} \mathrm{~K}$ (Megalovasilis, 1994; Karangelos et al., 2003; Stoulos et al., 2004; Petropoulos et al., 2004) and lignite burning is a source of technologically enhanced exposure to man from natural radionuclides.

The continuous studying of the content of Potentially Toxic Elements as well as the understanding of the origin and behaviour of such elements is a priority in the EU (and worldwide), but even more in countries that utilize fossil fuels, such as lignite, as an energy source. The present study aims at contributing towards this priority.

\section{Geological setting}

Ptolemais basin is part of the Florina-Vegoritis-Ptolemais Graben which is a large basin, filled with Neogene-Quaternary sediments, that has been developed between the mountains of Voras-Vernon to the east and Vermion-Askio to the west, and extends from the northern Bitola plain (FYROM) in a SSE direction to the hills of the Kozani area. It is almost $100 \mathrm{~km}$ long and about $15-20 \mathrm{~km}$ wide covering approximately $155 \mathrm{~km}^{2}$. In brief, the basin consists of Palaeozoic and Mesozoic rocks, either metamorphic or plutonic underlying limestone and flysch. The basement rocks can be divided into four tectonic units: 1. the pre-Alpine Pelagonian Basement, 2. the Almopia Unit, 3. the ultramafic-mafic Unit and 4. the Transgression Unit (Mountrakis et al., 1984).

\section{Materials and Methods}

\subsection{Sampling and sample preparation}

Amyntaion Power Station has two pulverised lignite-fired boilers. Samples were collected from the production lines and include pulverised lignite (PL), fly ash (FA) and bottom ash (BA). Black lignite samples (BL), wooden lignite (WL) and some intermediate steriles (i.e., conglomerates, sandstones, clays, marls, limestones, etc. that are interlayered with the lignite) samples (IS1, IS2, IS3, IS4) which were also collected from the stock piles just outside the production line. Lignite supplies for the power station vary even daily, in physical and chemical state because they originate from various 
coal-fields; therefore, it was decided to take monthly average samples together with the corresponding fly ash and bottom ash. Each sample was grinded prior to any further preparation and the particle size was reduced to 90 meshes using a mortar and a pestle. A more detailed description can be found in Megalovasilis et al. (2013).

\subsection{Bulk analyses and SEM-EDS}

XRF methods were used for the determination of 10 major and 11 trace elements in all the fly ash and bottom ash samples as well as in all the rock samples. Geochemical results were obtained for: $\mathrm{Si}, \mathrm{Al}, \mathrm{Fe}, \mathrm{Mn}, \mathrm{Mg}, \mathrm{K}, \mathrm{Na}, \mathrm{Ca}, \mathrm{P}, \mathrm{Ti}$, and $\mathrm{Pb}, \mathrm{Zn}, \mathrm{Cu}, \mathrm{Ba}, \mathrm{Cr}, \mathrm{Co}, \mathrm{Ni}, \mathrm{V}, \mathrm{U}, \mathrm{Th}, \mathrm{Rb}, \mathrm{Sr}, \mathrm{Y}, \mathrm{Nb}, \mathrm{Zr}$ and Sc. Internal standards were used in all cases and analysis was carried out with the use of Philips PW 1400 X-ray generator. Instrumental conditions used for XRF analyses for major and trace elements are those followed in routine geochemical analyses. However, the preparation and analysis was performed in the same way as that for fly ash, bottom ash and rock samples and consequently is relevant. Arsenic was determined only on limited samples using AAS Absorption of Ultraviolet and Visible radiation in a Unicam 8625 UV/VIS Spectrometer and AAS graphite furnace (B.S. 1016:, 1977). Cadmium was also analysed on limited samples applied with Varian GTA 96 Graphite Tube Atomiser following the same B.S. 1016 standard. Based on laboratory procedures and operating conditions, trace elements results with $5 \%$ precision and major elements results an $1 \%$ precision, should be considered. SEM-EDS images taken using a Jeol SEM.

\section{Results and Discussion}

\subsection{Major elements and related phases}

Analysis was carried out with the use of TR1 \& TR2 and MAJ software programmes, for trace and major elements respectively and analytical results stats are shown in Tables 1 and 2 . The analytical results concerning major elements in intermediate steriles (IS), fly ash (FA) and bottom ash (BA), are presented in Table 1, whereas the solid related phases appearing in microscale, also in lignites, are shown in Figures 1-6.

Table 1 - Concentration (wt.\%) of major elements in intermediate steriles (IS), fly ash (FA) and bottom ash (BA).

\begin{tabular}{|c|c|c|c|c|c|c|c|c|c|c|c|c|}
\hline & $\mathrm{SiO}_{2}$ & $\mathrm{TiO}_{2}$ & $\mathbf{A l}_{2} \mathbf{O}_{3}$ & $\mathrm{Fe}_{2} \mathrm{O}_{3}$ & MnO & MgO & $\mathrm{CaO}$ & $\mathrm{Na}_{2} \mathrm{O}$ & $\mathbf{K}_{2} \mathbf{O}$ & $\mathbf{P}_{2} \mathbf{O}_{5}$ & L.O.I. & Total \\
\hline IS1 & 2.66 & 0.05 & 1.02 & 1.08 & 0.05 & 4.46 & 89.5 & 1.80 & 0.22 & 0.18 & 0.00 & 100.0 \\
\hline IS2 & 58.5 & 1.35 & 23.3 & 5.35 & 0.07 & 2.51 & 3.28 & 2.11 & 2.72 & 0.20 & 0.00 & 99.4 \\
\hline IS3 & 57.3 & 1.30 & 22.8 & 5.21 & 0.07 & 2.49 & 3.20 & 1.96 & 2.65 & 0.21 & 0.00 & 97.1 \\
\hline IS4 & 15.9 & 0.28 & 5.05 & 3.89 & 0.11 & 6.24 & 66.1 & 0.69 & 0.50 & 0.09 & 0.00 & 98.9 \\
\hline FA1 & 34.8 & 0.72 & 13.9 & 6.79 & 0.07 & 4.07 & 32.3 & 1.54 & 1.16 & 0.26 & 4.05 & 95.6 \\
\hline FA2 & 35.7 & 0.70 & 13.6 & 6.50 & 0.07 & 3.95 & 31.5 & 1.92 & 1.20 & 0.25 & 3.37 & 95.4 \\
\hline FA3 & 34.0 & 0.69 & 13.7 & 6.52 & 0.06 & 4.16 & 33.1 & 1.38 & 1.19 & 0.24 & 4.29 & 95.5 \\
\hline BA1 & 44.6 & 0.88 & 16.4 & 8.55 & 0.06 & 3.72 & 19.6 & 0.76 & 1.35 & 0.25 & 38.3 & 96.2 \\
\hline BA2 & 44.4 & 0.83 & 15.4 & 8.39 & 0.08 & 3.69 & 21.7 & 0.58 & 1.30 & 0.23 & 37.5 & 96.9 \\
\hline BA3 & 39.9 & 0.86 & 14.3 & 9.21 & 0.07 & 3.73 & 22.1 & 0.76 & 1.22 & 0.23 & 64.3 & 92.7 \\
\hline
\end{tabular}




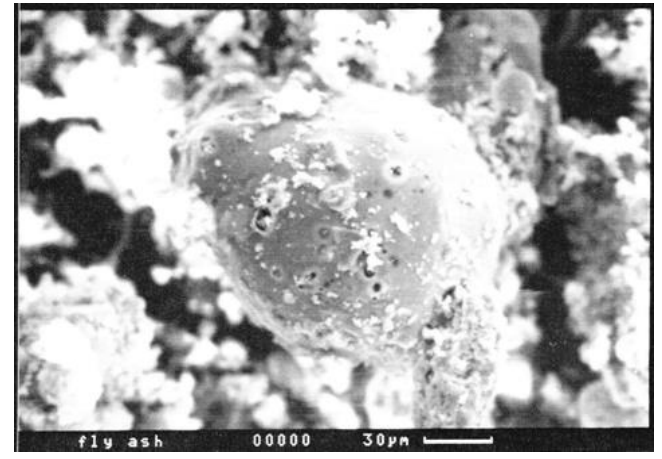

Figure 1 - Porous carbonaceous cenosphere.

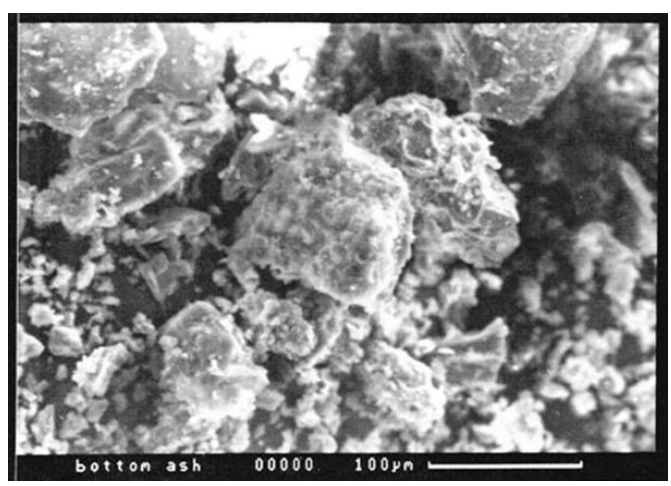

Figure 3 - Sulphate (gypsum-anhydrite) microparticles in $\mathbf{B A}$.

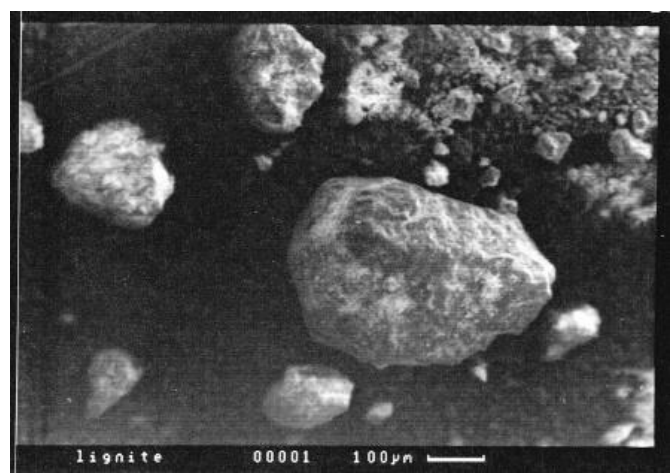

Figure 5 - Carbonaceous microparticles in lignite.

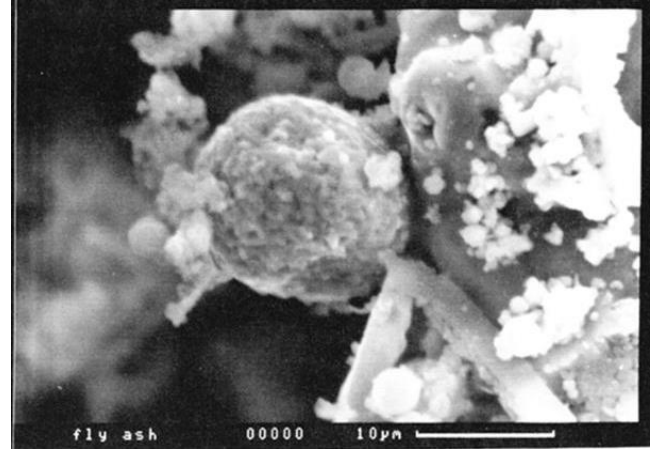

Figure 2 - Fe-oxide botryoidal spherule in $\mathbf{F}$ A.

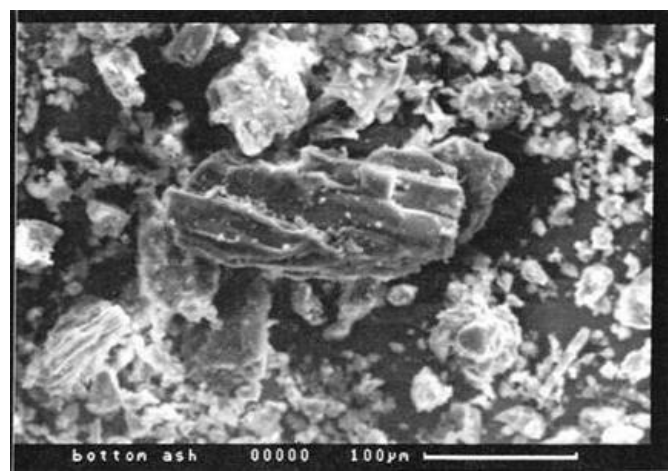

Figure 4 - Melilite (gehlenite-åkermanite) microparticle.

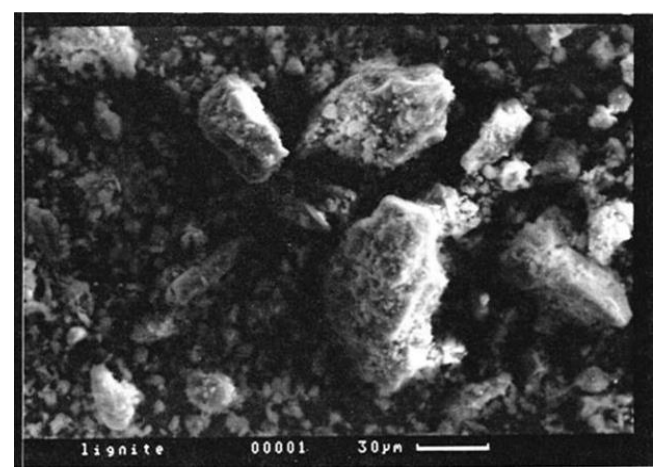

Figure 6 - Micro-fragments of feldspars in lignite.

It is evident that silicon is the predominant major element, in all types of samples examined by analytical and microscopic techniques. According to Koukouzas et al. (2009) the major lignite (inorganic) minerals are quartz and clays, whereas there are also organic minerals such as weddelite. Besides, calcium is also essential in all samples, occurring mainly in the form of $\mathrm{Ca}$-carbonate, $\mathrm{Ca}$ oxide, and Ca-sulphate microparticles. Moreover, iron seems to be essential in the case of ashes, forming porous and botryoidal Fe-oxide spherules. According to Filippidis et al. (1996), ashes may contain hematite together with a variety of $\mathrm{Ca}-\mathrm{Mg}$-silicates and $\mathrm{Ca}-\mathrm{Fe}-\mathrm{Ca}-\mathrm{Al}-\mathrm{Fe}$-oxides. It should be mentioned that, on the basis of the present results, and in accordance to previous works, there is 
no clear indication of distinct phases composed by elements of environmental interest, such as $\mathrm{Ni}$, $\mathrm{V}, \mathrm{Cr}, \mathrm{As}, \mathrm{U}$ and Th.

\subsection{Trace element geochemistry}

The analytical results concerning trace elements in intermediate steriles (IS), lignites (BL, WL \& PL), fly ash (FA) and bottom ash (BA) are presented in Table 2 and Figure 7.

Table 2 - Summary of trace element concentrations (ppm) in intermediate steriles (IS), lignites (BL, WL \& PL), fly ash (FA) and bottom ash (BA).

\begin{tabular}{|c|c|c|c|c|c|c|c|c|c|c|c|c|c|c|c|c|c|c|}
\hline & $\mathbf{P b}$ & $\mathbf{Z n}$ & $\begin{array}{l}\mathbf{C} \\
\mathbf{u}\end{array}$ & Ba & $\mathrm{Cr}$ & $\begin{array}{l}\text { C } \\
\text { o }\end{array}$ & $\mathrm{Ni}$ & $\mathbf{V}$ & $\mathbf{U}$ & $\begin{array}{l}\text { T } \\
\text { h }\end{array}$ & $\mathbf{R b}$ & $\mathbf{S r}$ & $\mathbf{Y}$ & $\begin{array}{l}\mathbf{N} \\
\mathbf{b}\end{array}$ & $\mathbf{Z r}$ & $\begin{array}{l}\text { S } \\
\mathbf{c}\end{array}$ & $\begin{array}{r}\mathbf{A} \\
\mathbf{s}\end{array}$ & $\begin{array}{l}\text { C } \\
\text { d }\end{array}$ \\
\hline IS1 & $<5$ & 14 & $<5$ & $\begin{array}{r}13 \\
7\end{array}$ & $<5$ & 3 & 4 & $<5$ & ங & 4 & 4 & $\begin{array}{r}26 \\
3\end{array}$ & く & $<2$ & $<5$ & $\begin{array}{l}1 \\
7\end{array}$ & & \\
\hline IS2 & 35 & $\begin{array}{r}16 \\
6\end{array}$ & 40 & $\begin{array}{r}54 \\
3\end{array}$ & $\begin{array}{r}29 \\
8\end{array}$ & 40 & $\begin{array}{r}16 \\
9 \\
\end{array}$ & $\begin{array}{r}18 \\
4\end{array}$ & $\begin{array}{l}< \\
3\end{array}$ & 18 & $\begin{array}{r}12 \\
3 \\
\end{array}$ & $\begin{array}{r}21 \\
21 \\
\end{array}$ & 40 & 21 & $\begin{array}{r}24 \\
4\end{array}$ & $\begin{array}{l}2 \\
0\end{array}$ & & \\
\hline IS3 & $<5$ & 16 & $<5$ & 40 & 18 & 3 & 20 & 8 & $\begin{array}{l}< \\
3\end{array}$ & 5 & 7 & 98 & 4 & $<2$ & 6 & $\begin{array}{l}2 \\
1\end{array}$ & & \\
\hline IS4 & $<5$ & 31 & 13 & $\begin{array}{r}11 \\
4 \\
\end{array}$ & 98 & 8 & $\begin{array}{r}10 \\
9\end{array}$ & 20 & 3 & 7 & 21 & $\begin{array}{r}26 \\
2\end{array}$ & 5 & 2 & 16 & $\begin{array}{l}2 \\
0\end{array}$ & & \\
\hline BL & $<5$ & 11 & 21 & 91 & 64 & 17 & 11 & 70 & 5 & 4 & 14 & $\begin{array}{r}10 \\
6\end{array}$ & 5 & 4 & 32 & 8 & & \\
\hline WL & $<5$ & 14 & 19 & 58 & 75 & 17 & 18 & $\begin{array}{r}26 \\
9 \\
\end{array}$ & $\begin{array}{l}< \\
3\end{array}$ & 3 & $<2$ & 52 & 4 & $<2$ & $<5$ & $\begin{array}{l}1 \\
2 \\
\end{array}$ & & \\
\hline PL & & & & & & & & & & & & & & & & & & \\
\hline MIN & 7 & 26 & 23 & $\begin{array}{r}15 \\
0 \\
\end{array}$ & $\begin{array}{r}12 \\
6 \\
\end{array}$ & 15 & 56 & 88 & 4 & 7 & 19 & $\begin{array}{r}12 \\
0 \\
\end{array}$ & 8 & 4 & 34 & $\begin{array}{l}1 \\
2\end{array}$ & 2 & 0.3 \\
\hline MAX & 9 & 31 & 35 & $\begin{array}{r}17 \\
7 \\
\end{array}$ & $\begin{array}{r}14 \\
2 \\
\end{array}$ & 20 & 67 & 96 & 6 & 8 & 23 & $\begin{array}{r}13 \\
0 \\
\end{array}$ & 10 & 5 & 36 & $\begin{array}{l}1 \\
4\end{array}$ & 3 & 0.5 \\
\hline $\begin{array}{r}\text { MEA } \\
\mathrm{N} \\
\end{array}$ & 8 & 28 & 28 & $\begin{array}{r}16 \\
6 \\
\end{array}$ & $\begin{array}{r}13 \\
5 \\
\end{array}$ & 18 & 62 & 91 & 5 & 8 & 21 & $\begin{array}{r}12 \\
6 \\
\end{array}$ & 9 & 4 & 35 & $\begin{array}{l}1 \\
3 \\
\end{array}$ & 3 & 0.4 \\
\hline FA & & & & & & & & & & & & & & & & & & \\
\hline MIN & 19 & 71 & 64 & $\begin{array}{r}44 \\
0 \\
\end{array}$ & $\begin{array}{r}15 \\
0 \\
\end{array}$ & 20 & $\begin{array}{r}17 \\
0 \\
\end{array}$ & $\begin{array}{r}10 \\
7 \\
\end{array}$ & 14 & 14 & 61 & $\begin{array}{r}33 \\
1\end{array}$ & 26 & 13 & 97 & $\begin{array}{l}1 \\
7\end{array}$ & 10 & 0.7 \\
\hline MAX & 23 & 77 & 77 & $\begin{array}{r}46 \\
9 \\
\end{array}$ & $\begin{array}{r}17 \\
1 \\
\end{array}$ & 20 & $\begin{array}{r}19 \\
1 \\
\end{array}$ & $\begin{array}{r}11 \\
4 \\
\end{array}$ & 17 & 15 & 63 & $\begin{array}{r}34 \\
2 \\
\end{array}$ & 27 & 13 & $\begin{array}{r}10 \\
8 \\
\end{array}$ & $\begin{array}{l}1 \\
8 \\
\end{array}$ & 16 & 2.0 \\
\hline $\begin{array}{r}\text { MEA } \\
\mathrm{N}\end{array}$ & 21 & 73 & 71 & $\begin{array}{r}45 \\
7 \\
\end{array}$ & $\begin{array}{r}16 \\
0 \\
\end{array}$ & 20 & $\begin{array}{r}17 \\
8 \\
\end{array}$ & $\begin{array}{r}11 \\
0 \\
\end{array}$ & 15 & 15 & 62 & $\begin{array}{r}33 \\
5 \\
\end{array}$ & 26 & 13 & $\begin{array}{r}10 \\
2 \\
\end{array}$ & $\begin{array}{l}1 \\
7 \\
\end{array}$ & 14 & 1.2 \\
\hline BA & & & & & & & & & & & & & & & & & & \\
\hline MIN & 5 & 29 & 8 & $\begin{array}{r}13 \\
8 \\
\end{array}$ & $\begin{array}{r}19 \\
8 \\
\end{array}$ & 26 & 83 & $\begin{array}{r}14 \\
8 \\
\end{array}$ & 7 & 7 & 25 & $\begin{array}{r}10 \\
7 \\
\end{array}$ & 13 & 5 & 40 & $\begin{array}{l}1 \\
4 \\
\end{array}$ & 3 & 0.4 \\
\hline MAX & 10 & 51 & 51 & $\begin{array}{r}34 \\
4 \\
\end{array}$ & $\begin{array}{r}22 \\
8 \\
\end{array}$ & 28 & $\begin{array}{r}12 \\
5 \\
\end{array}$ & $\begin{array}{r}20 \\
1 \\
\end{array}$ & 9 & 13 & 46 & $\begin{array}{r}19 \\
1 \\
\end{array}$ & 22 & 10 & 70 & $\begin{array}{l}1 \\
7 \\
\end{array}$ & 5 & 2.0 \\
\hline $\begin{array}{r}\text { MEA } \\
\mathrm{N}\end{array}$ & 7 & 41 & 33 & $\begin{array}{r}26 \\
7\end{array}$ & $\begin{array}{r}21 \\
6\end{array}$ & 27 & $\begin{array}{r}10 \\
8\end{array}$ & $\begin{array}{r}17 \\
3\end{array}$ & 9 & 10 & 38 & $\begin{array}{r}16 \\
0\end{array}$ & 18 & 8 & 59 & $\begin{array}{l}1 \\
5\end{array}$ & 4 & 0.9 \\
\hline
\end{tabular}

Trace elements in coal can occur as components of either the organic constituents (macerals) or the inorganic constituents (minerals). The concentrations and distribution of the trace elements are important in order to understand the geochemical conditions in which the coal was formed and in predicting the environmental impact of burning particular coals. It has been found that coal combustion is a significant atmospheric pollutant source for lead (Petaloti et al., 2006), but the amount of $\mathrm{Pb}$ emitted to the atmosphere from coal combustion is dependent upon its concentration in coal, type of boiler configuration and the effectiveness of control devices. The mode of occurrence of lead in coals, varies for different areas, and the main associations are with galena, pyrite, $\mathrm{PbSe}$, and some $\mathrm{Ba}$ minerals, where $\mathrm{Pb}$ can replace $\mathrm{Ba}$ (sulphates, carbonates and phosphates). $\mathrm{As}$ mentioned above, all of these potential phases have not been determined in the SEM-EDS investigation performed in the present study. Organic association is (e.g. in low rank coals) expected as well but in lesser extent. It has been observed that no significant amount of lead is volatized upon ashing, and studies of lead distribution vs. fly ash particle size demonstrated maximum concentration in the sub micron range while coal combustion contributes $6 \%$ or more to total atmospheric lead 
emissions (Valcovic, 1983). Lead average concentration in Ptolemais lignite is 8 ppm with a range of about 7-9 ppm. In fly ash the average concentration is $21 \mathrm{ppm}$ ranging from 19 to $23 \mathrm{ppm}$ and in bottom ash is $7 \mathrm{ppm}$ ranging from $5-10 \mathrm{ppm}$.

Zinc is an essential element and is required by living organisms, but in very small amounts. In the Ptolemais lignite $\mathrm{Zn}$ concentrations vary from $26-31 \mathrm{ppm}$ with an average value of $28 \mathrm{ppm}$. It has been suggested that $\mathrm{Zn}$ is organically bonded (i.e., in low-rank coals), but there have been many detections of sphalerite $[(\mathrm{Zn}, \mathrm{Fe}) \mathrm{S}]$, as well. In fly ash samples, $\mathrm{Zn}$ was found to be in the range of 71-77 ppm with an average of $73 \mathrm{ppm}$. In bottom ash, Zn levels are in the range 29-51 ppm while the average value is $41 \mathrm{ppm}$.
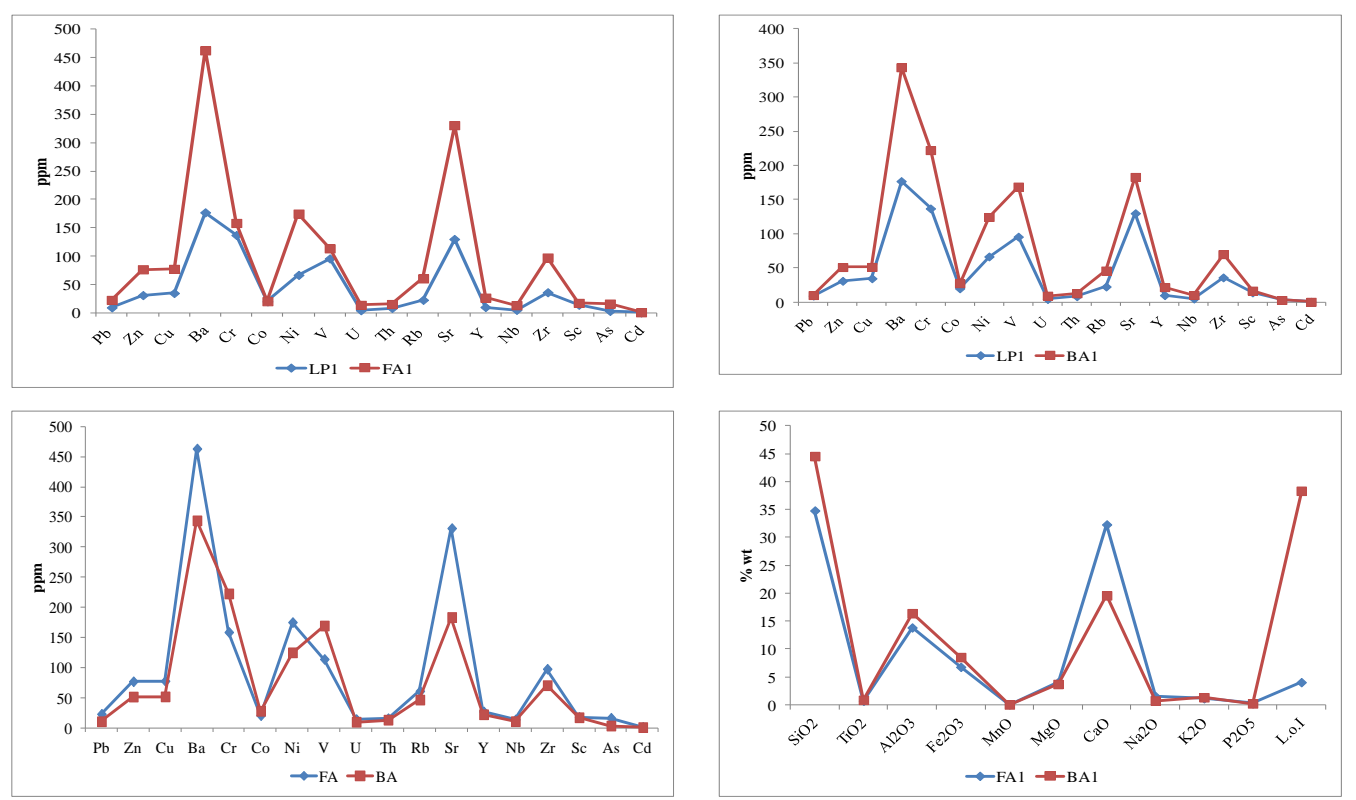

Figure 7 - Trace elements concentrations in lignite and combustion byproducts (FA and BA).

Copper is an essential element but excess is undesirable. Chalcopyrite is found in many coals, but other sulphide minerals of $\mathrm{Cu}$ occur occasionally (Swaine, 1990). The mode of occurrence of $\mathrm{Cu}$ in most coals is probably as a sulphide, usually Chalcopyrite $\left[\mathrm{CuFeS}_{2}\right]$ and associated with organic matter, especially in low-rank coals. In Ptolemais lignite, $\mathrm{Cu}$ concentration is between 23-35 ppm and while the average $\mathrm{Cu}$ content is $28 \mathrm{ppm}$. In the fly ash $\mathrm{Cu}$ has an average concentration of 71 $\mathrm{ppm}$ and a concentration range $64-77 \mathrm{ppm}$. In bottom ash samples $\mathrm{Cu}$ is within the range 8-51 and has an average concentration of $33 \mathrm{ppm}$.

Barium associates with Ba-bearing minerals e.g.: Barite $\left[\mathrm{BaSO}_{4}\right]$, Barytocelestine $\left[(\mathrm{Sr}, \mathrm{Ba}) \mathrm{SO}_{4}\right]$, Witherite $\left[\mathrm{BaCO}_{3}\right]$ and Gorceixite $\left[\mathrm{BaAl}_{3}\left(\mathrm{PO}_{4}\right)\left(\mathrm{PO}_{3} \mathrm{OH}\right)(\mathrm{OH})_{6}\right]$, and thus has an inorganic affinity although in some cases there is evidence for the association of $\mathrm{Ba}$ with organic coaly matter via carboxyl groups. Barium in Ptolemais lignite varies from 150 to $177 \mathrm{ppm}$ with an average concentration of $166 \mathrm{ppm} \mathrm{Ba}$. In fly ash $\mathrm{Ba}$ has a range from 440-469 ppm and an average concentration of $457 \mathrm{ppm}$. In bottom ash samples, Ba concentration found between 138 to 344 with an average of $267 \mathrm{ppm}$.

Chromium is not regarded as toxic, except in the hexavalent state, which may occur in some waste waters and industrial situations, but not usually during coal mining or usage. It is partly complexed with organic matter in some US lignites, but in addition, mineral matter association has been observed as well. Chromium in Ptolemais Lignite was found being in a range from 126 to $142 \mathrm{ppm}$ 
and with average concentration $135 \mathrm{ppm}$. In fly ash Cr ranges from 150 to $171 \mathrm{ppm}$ with average value $160 \mathrm{ppm}$, and in bottom ash from 198 to $228 \mathrm{ppm}$ with an average of $216 \mathrm{ppm}$.

Cobalt may occur in coal associated with the mineral matter (linnaeite, other sulphides, clay) and with organic matter. The range for Ptolemais lignite is $15-20 \mathrm{ppm}$ with a mean of 18 and for fly ash samples analysed the range is $16-23$ with a mean of $20 \mathrm{ppm}$. For the bottom ash sample Co found being in a range from 26-28 ppm with a mean of 27.

The major source of atmospheric $\mathrm{Ni}$ is form the combustion of fossil fuels. Nickel concentration in lignite is 56-67 ppm, with a mean of $62 \mathrm{ppm}$. In fly ash Ni concentration is ranging from 170-191 ppm with an average value $178 \mathrm{ppm}$ and in bottom ash is ranging from 83-125 with a mean of 108 ppm. The mode of occurrence is associated with sulphides (millerite, linneaeite) and organically associated (Finkelman, 1999).

Vanadium could be responsible for corrosion effects during utilisation and health effects at high levels. Vanadium is bound organically in some coals, while in other cases an inorganic association has been proposed. In lignite, $\mathrm{V}$ has an average concentration of $91 \mathrm{ppm}$, ranging from 88-96 ppm while in fly ash the mean is $110 \mathrm{ppm}$ and the range is $117-114 \mathrm{ppm}$. In bottom ash $\mathrm{V}$ has an average concentration of $173 \mathrm{ppm}$ and a range from 148-201 ppm.

Uranium is an element of environmental importance because is a source of radioactivity. Its concentration in lignite is $5 \mathrm{ppm}$ and it varies little (4 to $6 \mathrm{ppm}$ ). These values fall in range of other reported $U$ concentrations from adjacent lignitic fields in the area (Papanicolaou et al., 2004). In fly ash the mean is 15 and the fly ash samples fall in the range 14-17 ppm approximately. Regarding the bottom ash, the mean is $8.7 \mathrm{ppm}$ and the range observed is around 7-9 ppm. The modes of occurrence of $U$ in coal are diverse, but organic bonding seems general, together with associations with mineral matter (Swaine, 1990). Although U is not genetically associated with coaly substances (i.e., present in the original plant material), it may be picked up by coal during the course of migration and the fact that in some cases coalified wood materials in close proximity may or may not contain $\mathrm{U}$ demonstrates the effect of localised channelling of uranium- bearing waters. Uranium can form different minerals during its incorporation into coal e.g. uraninite and coffinite, depending on the composition of the original mineralizing fluid.

Thorium is another element that contributes to the radioactivity in coal and for that reason is of environmental importance. The mean value for the lignite samples is $7.5 \mathrm{ppm}$ and the range is from 7 to $8 \mathrm{ppm}$. Although $\mathrm{U}$ is the main source of radioactivity for Greek lignites, Th levels in fly ash and bottom ash indicate that its contribution to radioactivity of coal by-products, result from coal combustion cannot be negligible. Thorium has a mean of $15 \mathrm{ppm}$ in fly ash, while in bottom ash the mean value is $10 \mathrm{ppm}$. The range is $14-15 \mathrm{ppm}$ and 7-13 ppm for fly ash and bottom ash respectively. Thorium is associated with mineral matter in most coals, mainly as monazite, with lesser amounts in zircon, and xenotime (Finkelman, 1999).

Rubidium has no environmental or health significance, and is often associated with clays. In lignite, $\mathrm{Rb}$ has an average value of $21 \mathrm{ppm}$, ranging from 19-23 ppm. In fly ash and bottom ash the mean is 62 and 38 ppm respectively, and the range is 61-63 ppm for fly ash and 25-46 ppm for bottom ash.

It has been suggested (Finkelman, 1999), that Strontium is associated with organic matter in most low-rank coals, whereas other coals also contain Sr associated with phosphate minerals and in some cases, calcite. Strontium's mean value in lignite samples is 126 , while in fly ash and bottom ash samples the average concentration is 335 and $160 \mathrm{ppm}$, respectively. The corresponding ranges were: 120-130 ppm, 331-342 ppm and 107-191.

Partly organic but mostly inorganic association has been proposed for the presence of Y in coals where $\mathrm{Y}$ found in fined-grained xenotime $\mathrm{YPO}_{4}$. In lignite $\mathrm{Y}$ mean is $8 \mathrm{ppm}$, in fly ash is $26 \mathrm{ppm}$ and in bottom ash is 18 , while the corresponding ranges are: $8-10 \mathrm{ppm}, 26-28 \mathrm{ppm}$ and 13-22 ppm. 
Accumulation of $\mathrm{Y}$ can be derived from leaching of the overlying sandstones and sorption by organic matter and Y undergoes local redistribution (Finkelman, 1999).

Niobium in lignite has an average concentration of $4 \mathrm{ppm}$. In fly ash and bottom ash samples analysed the mean is 13 and 8 ppm, respectively. The corresponding ranges are: 4-5 ppm, 12.8-13.4 ppm and 5-10 ppm approximately. The mode of occurrence of $\mathrm{Nb}$ in coals has not well defined yet and is different in various coals. In some coals $\mathrm{Nb}$ is organically associated and with mineral matter, whereas in some coal from USA, most of Nb was associated with Rutile (Finkelman, 1999). Both mineralogical and organic associations have been reported for this element although it is mainly associated with mineral matter (Swaine, 1990).

Zircon is regarded as the main mode of occurrence of $\mathrm{Zr}$ in most coals. $\mathrm{Zr}$ in lignite has an average concentration of 35 and a range from 34-36 ppm. In fly ash the mean is $102 \mathrm{ppm}$ and in bottom ash the mean is $59 \mathrm{ppm}$ while the range of $\mathrm{Zr}$ in fly ash and bottom ash is $92-108 \mathrm{ppm}$ and 40-70 ppm, respectively.

Scandium is not considered to be essential or harmful in biological systems. There is an agreement that Sc occurs associated with the mineral matter and with the organic matter in varying proportions. Perhaps clays and phosphate minerals are sites for Sc in some coals (Finkelman, 1999). In lignite it has an average concentration of $13 \mathrm{ppm}$ and a range from 12-14 ppm, in fly ash the mean is 17 and in bottom ash is 15 while the ranges are approximately: $17-18 \mathrm{ppm}$ and 14-17 ppm, respectively.

Arsenic is an element of greatest concern, regarding its potential toxicity (Gamaletsos et al., 2013). Both inorganic and organic forms of As are present in coal. Finkelman (1999), noted that As was predominantly in fractures in the coal and in microfractures in pyrite but it was, also found that As was present in solid solution in pyrite. The average concentration of As in lignite is approximately $3 \mathrm{ppm}$, in fly ash the mean is 14 and in bottom ash is $4 \mathrm{ppm}$, respectively.

Cadmium is an element of prime environmental concern and its levels in coal and its by-products are of great interest. Minor amounts of $\mathrm{Cd}$ are organically associated in most coals but the main mode of occurrence in most coals is associated with mineral matter i.e.: sphalerite, clay minerals and carbonate minerals or pyrite. Cadmium average concentration in those lignite samples analysed, is $0.411 \mathrm{ppm}$ approximately. In fly ash the mean value is round $1.2 \mathrm{ppm}$ and in bottom ash the mean is $0.9 \mathrm{ppm}$ approximately, while values of $2 \mathrm{ppm}$ were found in both ashes.

In general, the enrichments of the trace elements are in accordance with other related works (Megalovasilis et al., 2013) and can be attributed to the local geology (Petrotou et al., 2010, 2012). The same studies claim that a possible origin of $U$ and Th could be from schists and other, similar, local rock types found in the area.

\section{Conclusions}

Considering the data presented herein, it can be concluded that the environmental geochemistry of Ptolemais lignites and intermediate steriles (IS), as well as of subsequent combustion by-products mainly concerns $\mathrm{Cr}, \mathrm{Ni}, \mathrm{V}, \mathrm{U}$, Th and As. Chromium concentration is rather low in IS samples, but the metal is particularly concentrated in lignites (max: $64-142 \mathrm{ppm}$ ) and additionally in FA and BA. Nickel and V concentrations are rather surprisingly high in IS samples (max: 169 and $184 \mathrm{ppm}$ respectively), and of course, more accumulated in FA and BA. On the other hand, As is relatively absent in IS samples and elevated in ashes (min - max: 10 - $16 \mathrm{ppm}$ ), indicating lignites as the source. Actinides, namely $U$ and Th, are also enriched in FA and BA (min - max: 14 - 17 ppm and $14-15$ ppm respectively). A perfect coupling between elemental concentration between lignites, FA and BA was observed, indicating similar chemical processes during combustion. Further investigation, by means of advanced microscopic and spectroscopic techniques (e.g. FEG-SEM, TEM, XAS) is need in order to clarify the trace element partitioning and speciation in all earth materials studied. 


\section{Acknowledgments}

We would like to thank the Department of Earth Science and Environment of University of Leeds, UK, for permitting analyses of all samples using most analytical facilities available.

\section{References}

Filippidis, A. and Georgakopoulos, A., 1992. Mineralogical and chemical investigation of fly ash from the Main and Northern lignite fields in Ptolemais, Greece, Fuel, 71(4), 373-376.

Filippidis, A., Georgakopoulos, A., Kassoli-Fournaraki, A., Misaelides, P., Yiakkoupis, P. and Broussoulis, J., 1996. Trace element contents in composited samples of three lignite seams from the central part of the Drama lignite deposit, Macedonia, Greece, International Journal of Coal Geology, 29(4), 219-234.

Finkelman, R.B., 1999. Trace Elements in Coal Environmental and Health Significance, Biological Trace Element Research, 67(3), 197-204.

Foscolos, A.E., Goodarzi, F., Koukouzas, C.N. and Hatziyannis, G., 1989. Reconnaissance study of mineral matter and trace elements in Greek lignites, Chemical Geology, 76(1-2), 107-130.

Gamaletsos, P., Godelitsas, A., Dotsika, E., Tzamos, E., Gotthlicher, J. and Filippidis, A., 2013. Geological sources of As in the Environment of Greece: A review. In: Threats to the Quality of Groundwater Resources: Prevention and Control, Scozzari, A. and Dotsika, E., eds., Springer, Berlin, The Handbook of Environmental Chemistry, 40, 77-113.

Georgakopoulos, A., Filippidis, A. and Kassoli-Fournaraki, A., 1994. Morphology and trace element contents of the fly ash from main and Northern lignite fields, Ptolemais, Greece, Fuel, 73(11), 1802-1804.

Giannouli, A., Kalaitzidis, S., Siavalas, G., Chatziapostolou, A., Christanis, K. and Papazisimou, S., 2009. Evaluation of Greek low-rank coals as potential raw material for the production of soil amendments and organic fertilizers, International Journal of Coal Geology, 77(3), 383-393.

Iordanidis, A., Buckman, J., Triantafyllou A.G. and Asvesta, A., 2008. Fly ash-airborne particles from Ptolemais-Kozani area, northern Greece, as determined by ESEM-EDX, International Journal of Coal Geology, 73(1), 63-73.

Karangelos, D.J., Petropoulos, N.P., Anagnostakis, M.J. Hinis, E.P. and Simopoulos, S.E., 2004. Radiological characteristics and investigation of the radioactive equilibrium in the ashes produced in lignite-fired power plants, Journal of Environmental Radioactivity, 77(3), 233-246.

Kolovos, N., Georgakopoulos, A., Filippidis, A. and Kavouridis, C., 2002a. The effects on the mined lignite quality characteristics by the intercalated thin layers of carbonates in Ptolemais mines, Northern Greece, Energy Sources, 24(8), 761-772.

Kolovos, N., Georgakopoulos, A., Filippidis A. and Kavouridis, C., 2002b. Utilization of lignite reserves and simultaneous improvement of dust emissions and operation efficiency of a power plant by controlling the calcium (total and free) content of the fed lignite. Application on the Agios Dimitrios power plant, Ptolemais, Greece, Energy and Fuels, 16(6), 1516-1522.

Koukouzas, N., Hämäläinen, J., Papanikolaou, D., Tourunen, A. and Jäntti, T., 2007. Mineralogical and elemental composition of fly ash from pilot scale fluidised bed combustion of lignite, bituminous coal, wood chips and their blends, Fuel, 86(14), 2186-2193.

Koukouzas, N., Ward, C.R., Papanikolaou, D., Li, Z. and Ketikidis, C., 2009. Quantitative evaluation of minerals in fly ashes of biomass, coal and biomass-coal mixture derived from circulating fluidised bed combustion technology, Journal of Hazardous Materials, 169(1-3) 100-107.

Koukouzas, N., Zeng, K.R., Perdikatsis, V., Xu, W. and Kakaras, E.K., 2006. Mineralogy and geochemistry of Greek and Chinese coal fly ash, Fuel, 85(16) 2301-2309.

Megalovasilis, P., 1994. Environmental aspects in relation to the lignite combustion at the Power Station of Amyntaion, Macedonia, Greece, Bulletin of the Geological Society of Greece, $\mathrm{XXX} / 4,45-55$. 
Megalovasilis, P., Papastergios, G. and Filippidis, A., 2013. Behavior study of trace elements in pulverized lignite, bottom ash and fly ash of Amyntaio power station, Greece, Environmental Monitoring and Assessment, 185, 6071-6076.

Mountrakis, D., Dixon, J.E. and Robertson, A.H.F., 1984. Structural evolution of the Pelagonian Zone in Northwestern Macedonia, Greece. In: The Geological Evolution of the Eastern Mediterranean, Spec. Publs Geol. Soc. Lond., 17, 581-591.

Papanicolaou, C., Kotis, T., Foscolos, A. and Goodarzi, F., 2004. Coals of Greece: a review of properties, uses and future perspectives, International Journal of Coal Geology, 58(3), 147-169.

Petaloti, C., Triantafyllou, A., Kouimtzis, T. and Samara, C., 2006. Trace elements in atmospheric particulate matter over a coal burning power production area of western Macedonia, Greece, Chemosphere, 65, 2233-2243.

Petrotou, A., Skordas, K., Papastergios, G., and Filippidis, A., 2010. Concentrations and bioavailability of potentially toxic elements in soils of an industrialised area of Northwestern Greece. Fresenius Environmental Bulletin 19(12), 2769-2776.

Petrotou, A., Skordas, K., Papastergios, G. and Filippidis, A., 2012. Factors affecting the distribution of potentially toxic elements in surface soils around an industrialized area of northwestern Greece, Environmental Earth Sciences, 65(3), 823-833.

Riga-Karandinos, A.N. and Karandinos, M.G., 1998. Assessment of air pollution from a lignite power plant in the plain of Megalopolis (Greece) using as biomonitors three species of lichens; impacts on some biochemical parameters of lichens, The Science of The Total Environment, 215(1-2), 167-183.

Skodras, G., Grammelis, P., Kakaras, E., Karangelos, D., Anagnostakis, M. and Hinis, E., 2007. Quality characteristics of Greek fly ashes and potential uses, Fuel Processing Technology, 88(1), 77-85.

Stoulos, S., Manolopoulou, M. and Papastefanou, C., 2003. Assessment of natural radiation exposure and radon exhalation from building materials in Greece, Journal of Environmental Radioactivity, 69(3), 225-240.

Stoulos, S., Manolopoulou, M. and Papastefanou, C., 2004. Measurement of radon emanation factor from granular samples: effects of additives in cement, Applied Radiation and Isotopes, 60(1), 49-54.

Swaine, D.J., 1990. Trace Elements in Coal, 278 pp.

Valcovic, V.T.E., 1983. Trace Elements in Coal Volume I and Volume II, CRC Press.

Vamvuka, D., Kastanaki, E., Lasithiotakis, M. and Papanicolaou, C., 2004. Combustion behavior of xylite/lignite mixtures, Carbon, 42(2), 351-359.

Vamvuka, D., Pitharoulis, M., Alevizos, G., Repouskou, E. and Pentari, D., 2009. Ash effects during combustion of lignite/biomass blends in fluidized bed, Renewable Energy, 34(12), 26622671.

Vejahati, F., Xu, Z. and Gupta, R., 2010. Trace elements in coal: Associations with coal and minerals and their behavior during coal utilization - A review, Fuel, 89(4), 904-911.

Yan, L., Gupta, R.P. and Wall, T.F., 2001. The implication of mineral coalescence behaviour on ash formation and ash deposition during pulverised coal combustion, Fuel, 80(9), 1333-1340.

Zeevaert, T., Sweeck, L. and Vanmarcke, H., 2006. The radiological impact from airborne routine discharges of a modern coal-fired power plant, Journal of Environmental Radioactivity, 85(1), 1-22. 